Department of Anatomy (Prof. H. Fujita) and Department of Gynecology (Prof. A. Fujiwara), Hiroshima University School of Medicine, Hiroshima, Japan

\title{
Kinetics of Protein Synthesis and Release in the STH-Cell of the Mouse Anterior Pituitary as Revealed by Electron Microscopic Autoradiography of ${ }^{3} \mathrm{H}$-Amino Acids
}

\author{
Masamichi Hiura, Masanobu Komatsu and Hisao Fujita
}

Received September 25, 1975

\begin{abstract}
Summary. In order to investigate the kinetics of the synthesis and release of the secretory protein in the STH-secreting cell of the pituitary anterior lobe, studies were made using the electron microscopic autoradiography of ${ }^{3} \mathrm{H}$-amino acids. Each mouse received an intravenous injection of $2.8 \mathrm{mCi}$ of ${ }^{3} \mathrm{H}$-amino acids consisting of equal amounts of ${ }^{3} \mathrm{H}$ leucine, ${ }^{3} \mathrm{H}$-tyrosine, ${ }^{3} \mathrm{H}$-lysine, ${ }^{3} \mathrm{H}$-histidine and ${ }^{3} \mathrm{H}$-glycine. The animal was sacrificed at $3,5,15$ and $30 \mathrm{~min}, 1,2,4,8$ and $24 \mathrm{hrs}$ after the injection.

Although the whole silver grains are very few $3 \mathrm{~min}$ after the injection, half of the grains are recognized over the $\mathrm{r}-\mathrm{ER}(\mathbf{4 7 . 1} \%)$; the Golgi apparatus already shows a few grains $(5.9 \%)$. Total silver grains over the STH-cell increase in number with the lapse of time; the ratio of the grain number over the r-ER to the total grains over the whole cell decreases gradually, while the ratio of the grain number over the Golgi apparatus increases to reach a peak about $30 \mathrm{~min}$ after the injection $(40.1 \%)$ and then decreases gradually.

The ratio of the number of labelled granules to that of total granules increases slowly until 24 hrs after the injection ( $3 \mathrm{~min}: 0 \%, 5 \mathrm{~min}: 0.8 \%, 30 \mathrm{~min}: 3.9 \%, 2 \mathrm{hrs}: 5.0 \%, 8 \mathrm{hrs}$ : $8.0 \%, 24$ hrs : $12.3 \%$ ).

It is concluded that the turnover in synthesis and release of exportable protein in the mouse STH-cell is very slow as compared with that of the thyroid and parathyroid cell.
\end{abstract}

It has been well known that the exportable protein in the protein secreting cells is synthesized in the rough endoplasmic reticulum and transported to the Golgi apparatus to mature into secretory granules (CARo and PALAdE, 1964; PoHr et al., 1967; Jamieson and Palade, 1967; Fujita, 1970; NAKAGami et al., 1971; CAstle et al., 1972; SLot and Geuze, 1974 and so on).

Concerning the kinetics of the synthesis and release of the secretory protein of the pituitary anterior lobe cells, many autoradiographic studies have been made by TIXIERVidal and Picart (1967), Howell and WhitField (1973), Hopkins and Farquhar (1973) and so on. However, these studies were done in vitro using cultured tissues, and works dealing with the secretory kinetics of the anterior pituitary cells of the living animal are difficult to find except for that of RACADOT et al. (1965).

There are at least 6 kinds of hormones secreted from the pituitary anterior lobe. Among them somatotrophic hormone (STH) has been believed to be secreted from the cell having round secretory granules $250-350 \mathrm{~nm}$ in diameter, with high electron density, since HEDINGER and FARQUHAR (1957). The present paper deals with the turnover of the secretory protein in the STH-cell of the normal mouse pituitary anterior lobe.

\section{Materials and Methods}

Nine male mice, 6-month-old, 35-40 g in body weight, and brothers of the same mother, were used for this study. They were kept in the laboratory room at $25^{\circ} \mathrm{C}$ 
without feeding for 1 day before the experiment. Each animal was injected intravenously with $2.8 \mathrm{mCi}$ of mixture of ${ }^{3} \mathrm{H}$-amino acids consisting of L-leucine-4-5${ }^{3} \mathrm{H}$, L-tyrosine-3-5- ${ }^{3} \mathrm{H}$, L-lysine-4-5- ${ }^{3} \mathrm{H}(\mathrm{n})$ monohydrochloride, L-histidine-2-5- ${ }^{3} \mathrm{H}$ and glycine-2- ${ }^{3} \mathrm{H}$. At $3,5,15$ and $30 \mathrm{~min}, 1,2,4,8$ and $24 \mathrm{hrs}$ after the injection, the animals were perfused with $4 \%$ formaldehyde solution adjusted at $\mathrm{pH} 7.4$ with 0.1 M Sörensen's phosphate buffer. Their pituitary anterior lobes were removed, fixed for 2 hrs in the same solution and postfixed with $1 \% \mathrm{OsO}_{4}$ adjusted at $\mathrm{pH} 7.4$ with $0.1 \mathrm{M}$ Sörensen's phosphate buffer for 2 hrs. Then the tissues were dehydrated by ethanol and embedded in Epon.

For light microscopic autoradiography, $1 \mu$ thick Epon sections were coated with Sakura NR-M2 emulsion by the dipping method and exposed for about 4 months. After the exposure, the autoradiograms were developed in Kodak Microdol X for 5 min at $20^{\circ} \mathrm{C}$. The sections were stained with $0.5 \%$ toluidine blue.

For electron microscopic autoradiography, light gold colored sections were cut with Porter-Blum MT-1 ultramicrotome, mounted on collodion coated copper grids, stained with Millonig's lead solution (Millonig, 1961), coated with thin layer of carbon and covered with Ilford L4 photographic emulsion using the wire loop method. After the exposure of 4 months, the autoradiograms were developed in Kodak Microdol X for $5 \mathrm{~min}$ at $20^{\circ} \mathrm{C}$ or phenidone developer (Lettrè and Paweletz, 1966) for $1 \mathrm{~min}$ at $20^{\circ} \mathrm{C}$. After removal of the gelatin by treatment of a few min in $0.05 \mathrm{~N} \mathrm{NaOH}$, each grid was stained again with MilloniG's lead solution and examined in a Hitachi HU7S Type electron microscope. The autoradiograms were photographed at random so that at least the whole cell body of one STH-cell could be seen in one field of the electron microscope and silver grains were counted over various kinds of cell structures of the STH-cell.

The number of grains over each cell structure was expressed as percentage of the total grain number counted over the glandular cell for each particular time interval after the injection of ${ }^{3} \mathrm{H}$-amino acids. The ratio of the number of labelled granules to that of the total granules was calculated. The number of grains due to background fog was very low.

\section{Result}

In light microscopic autoradiograms, silver grains are distributed sparsely over the nucleus and cytoplasm $3 \mathrm{~min}$ after the intravenous injection of ${ }^{3} \mathrm{H}$-amino acids (Fig. 1a). Then grains are increased in number with the passage of time, especially the region next to the nucleus after 15 and $30 \mathrm{~min}$ (Fig. 1b, c). About $1 \mathrm{hr}$ after the injection grains are more increased in number (Fig. 1d). Then the number of the grains becomes almost stable 2, 4, 8 and 24 hrs after the in jection (Fig. 1e, f, g, h).

In electron microscopic autoradiographs at $3 \mathrm{~min}$ after the intravenous injection of ${ }^{3} \mathrm{H}$-amino acids half grains of silver are observed over the rough endoplasmic reticulum (r-ER), although total grains are very few in number. No silver grains were localized over secretory granules, though the mitochondria, Golgi apparatus and nucleus show a few grains. At $5 \mathrm{~min}$ after the in jection, silver grains are recognized over the r-ER as well as the Golgi apparatus (Fig. 2,3). A few secretory granules are labelled within 5 min. By 15 min after the injection a great number of silver grains are seen over the Golgi apparatus and those over the r-ER are decreased (Fig. 4). Some of the 

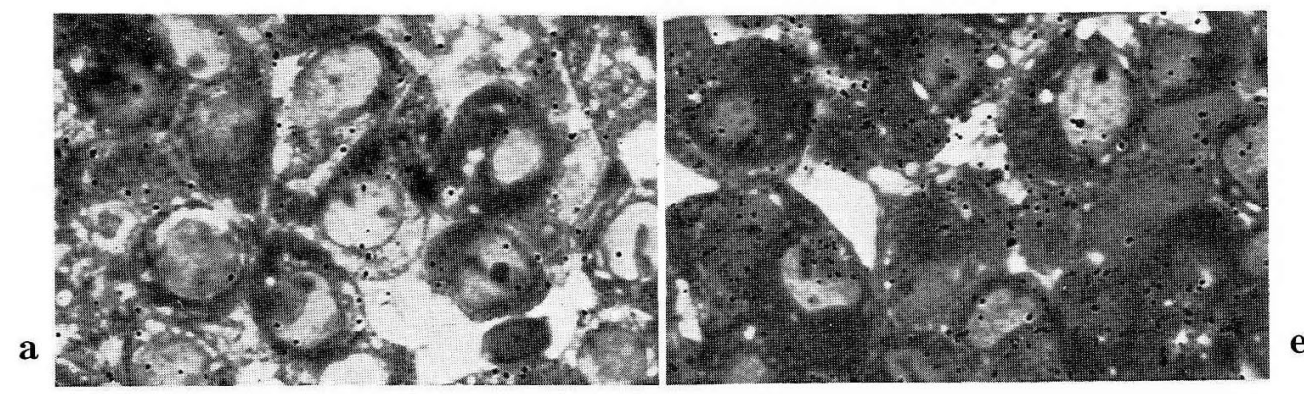

b
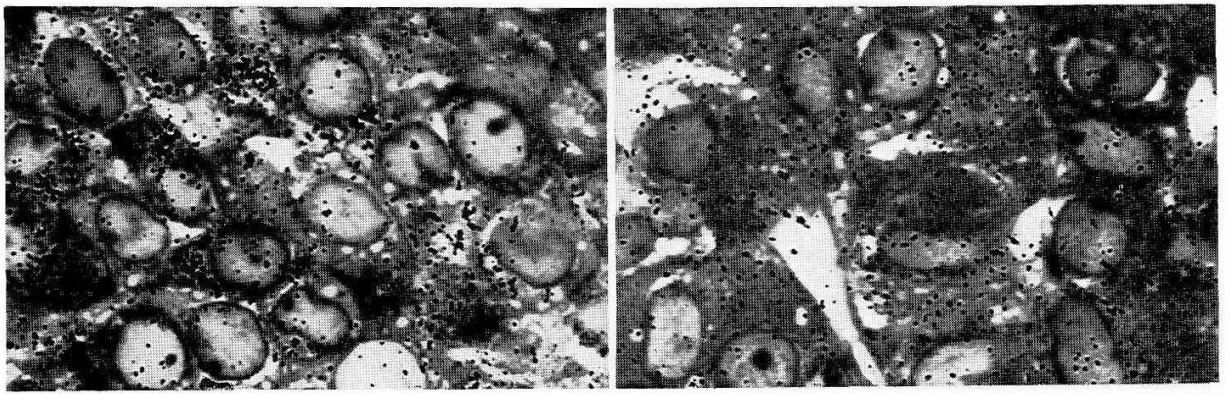

c
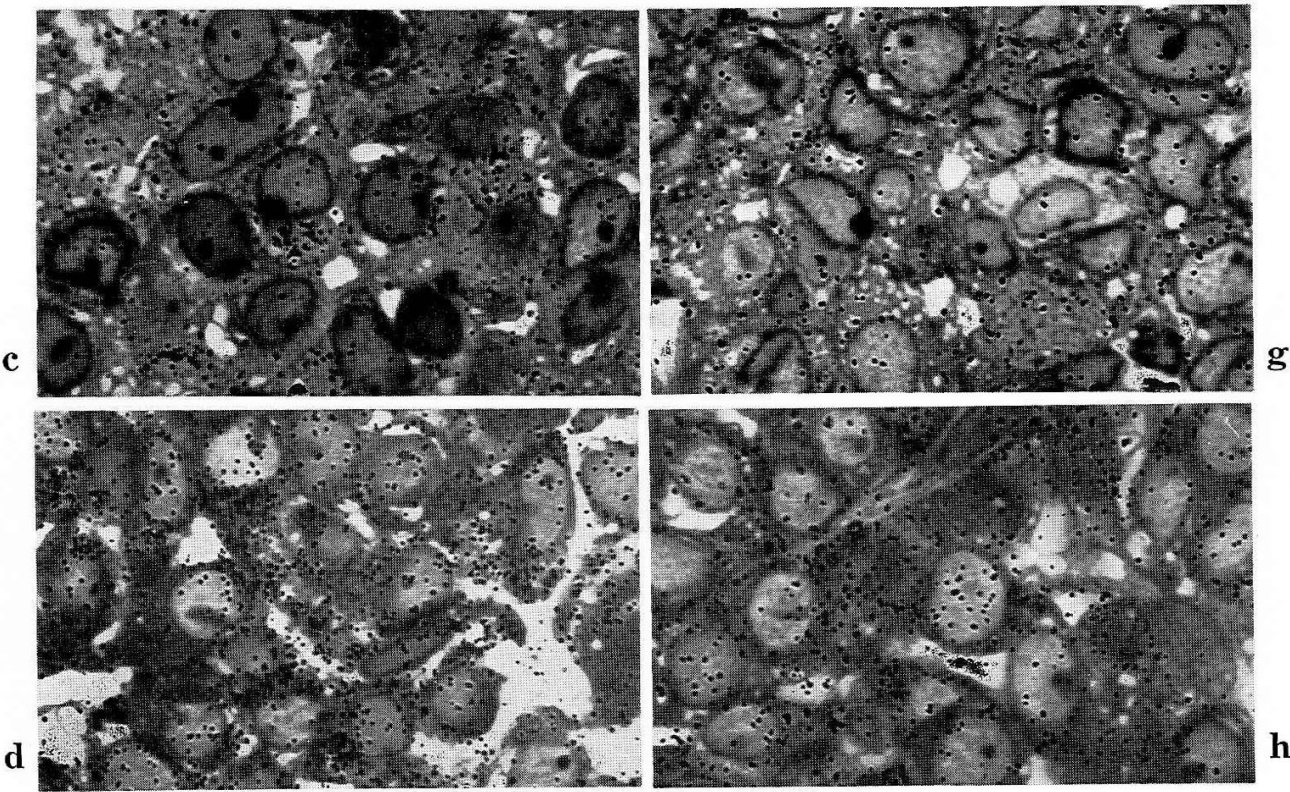

Fig. 1. Light microscopic autoradiographs of a part of the anterior pituitary. $\times 650 \quad$ a. 3 min after the injection of ${ }^{3} \mathrm{H}$-amino acids. Silver grains are distributed sparsely over the nucleus and cytoplasm. b and c. 15 and $30 \mathrm{~min}$ after the injection of ${ }^{3} \mathrm{H}$-amino acids. Most silver grains are concentrated next to the nucleus. d. $1 \mathrm{hr}$ after the injection of ${ }^{3} \mathrm{H}$-amino acids. $\mathbf{e}, \mathbf{f}, \mathbf{g}$ and $\mathbf{h}$. $2,4,8$ and $24 \mathrm{hrs}$ after the injection of ${ }^{3} \mathrm{H}$-amino acids. The number of the grains becomes almost stable. 


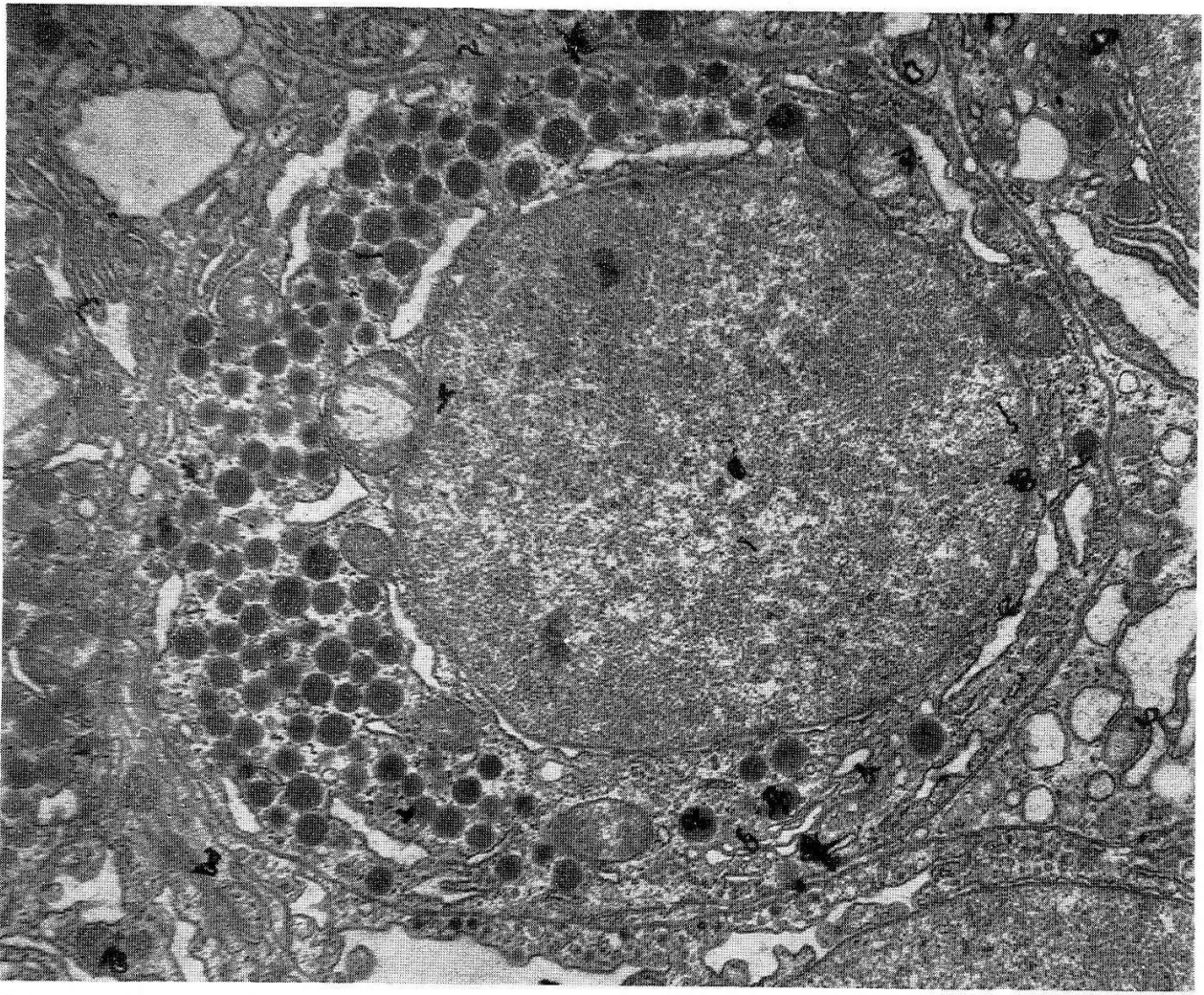

Fig. 2. An electron microscopic autoradiograph of the STH-cell $5 \mathrm{~min}$ after the injection of ${ }^{3} \mathrm{H}$ amino acids. A few silver grains are located over the Golgi apparatus. $\times 9,100$

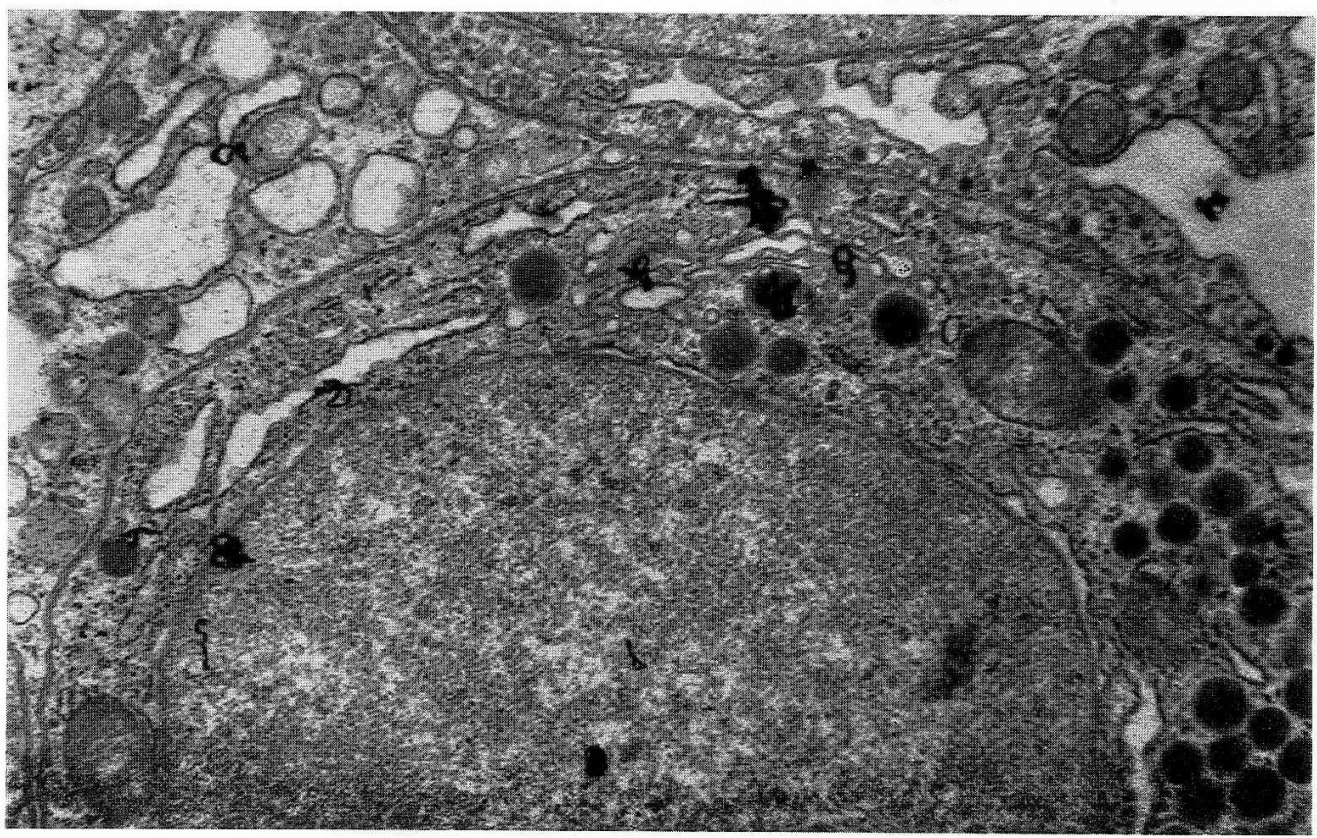




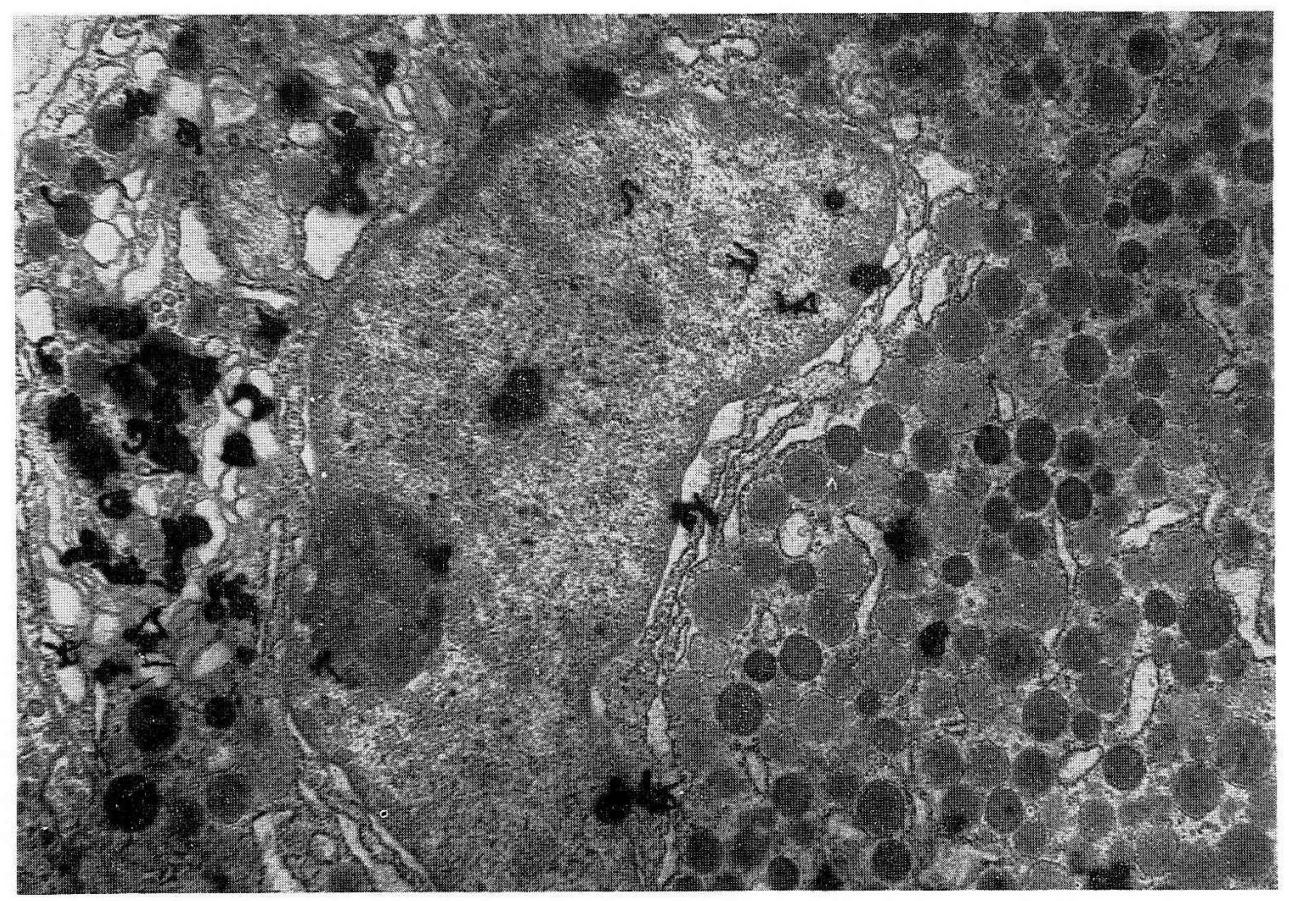

Fig. 4. An clcctron microscopic autoradiograph of the STH-cell $30 \mathrm{~min}$ after the injection of ${ }^{3} \mathrm{H}-$ amino acids. Most silver grains are recognized over the Golgi apparatus and a few grains are seen over the $r-E R$ and nucleus. $\times 11,400$

secretory granules and nucleoplasm are also labelled. At $1 \mathrm{hr}$ after the injection most silver grains are seen over the Golgi apparatus and secretory granules, while those over the r-ER are decreased.

At 2, 4 and 8 hrs after the in jection, most silver grains are observed over the secretory granules (Fig. 5, 6). Some silver grains are present over the nucleus. At 24 hrs after the injection the number of silver grains are seen prominently over the secretory granules. Counts over cell structures reveal that the ratio of the number of the silver grains over the r-ER to that of the total grains over the whole cell is the highest $(47.1 \%)$ at $3 \mathrm{~min}$ after the injection and decreases rapidly thereafter (Table 1 ). The ratio of the number of the silver grains over the Golgi apparatus to that of the total grains over the whole cell increases to reach a peak (40.1\%) about $30 \mathrm{~min}$ after the injection and then decreases until $24 \mathrm{hrs}(10.4 \%)$. The number of the silver grains over the secretory granulcs is zcro $3 \mathrm{~min}$ after the in jection and increases with the passage of time, especially showing a rapid increase at $1-2 \mathrm{hr}(26.5-41.7 \%)$. Thereafter it increases gradually until 24 hrs $(60.9 \%)$. The ratio of the number of labelled granules to that of the total granules shows a slow increase until 24 hrs after the injection $(12.3 \%$ ) (Table 3$)$.

Fig. 3. An electron microscopic autoradiograph of a part of the STH-cell 5 min after the injection of ${ }^{3} \mathrm{H}$-amino acids. A few silver grains are located over the Golgi apparatus and two labelled secretory granules are present. $\times 14,300$ 


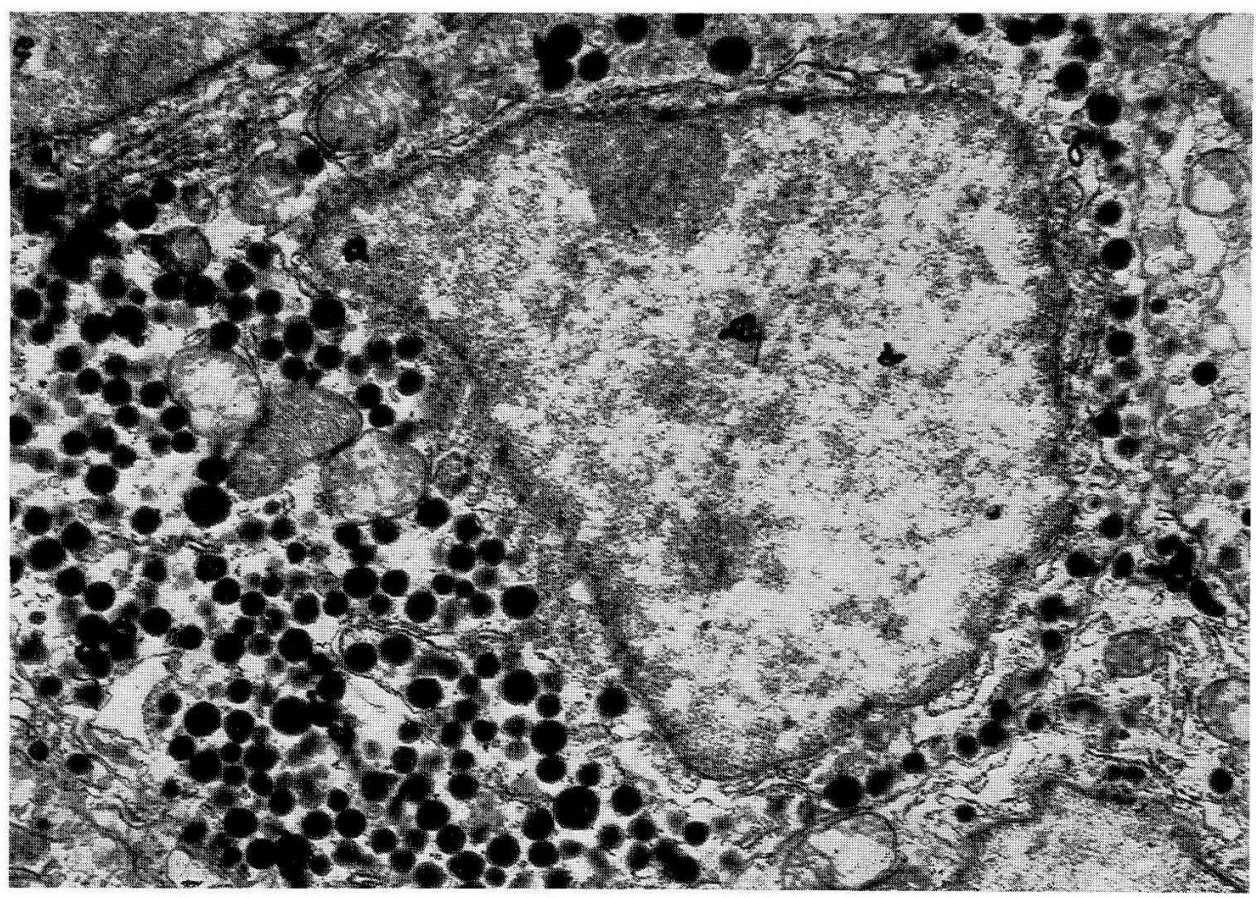

Fig. 5. An electron microscopic autoradiograph of the STH-cell 8 hrs after the injection of ${ }^{3} \mathrm{H}$ amino acids. Some silver grains are recognized over the secrotory granules and a few are over the nucleus. $\times 11,300$

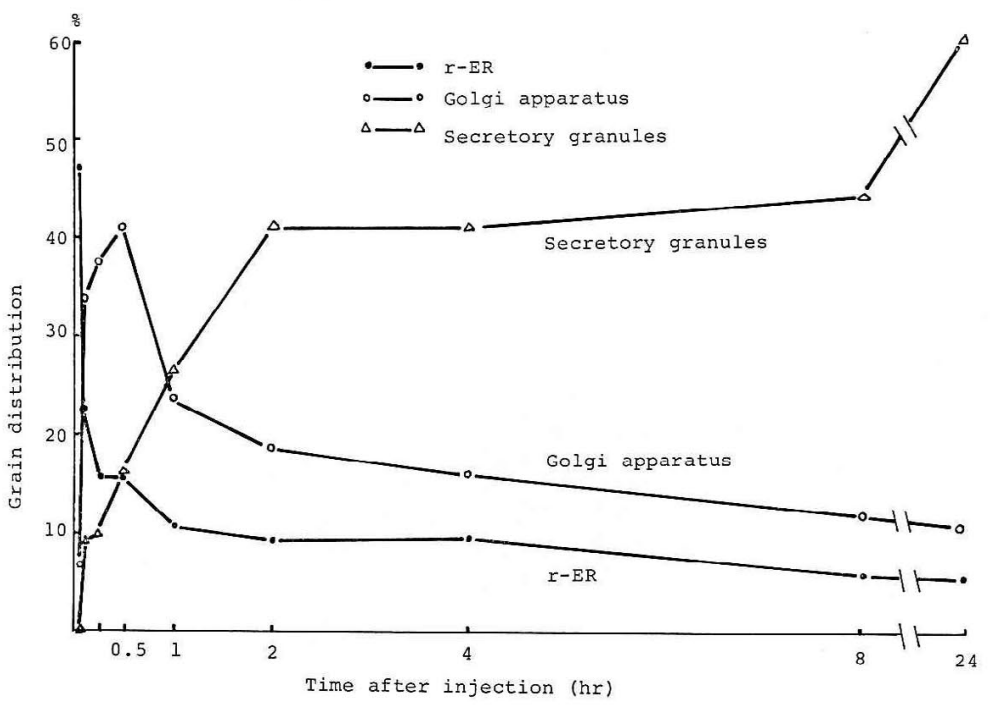

Fig. 6. Percentage of the number of silver grains over each cell component to that over the whole STH-cell at various times after the injection of ${ }^{3} \mathrm{H}$-amino acids. 
Table 1. Distribution of autoradiographic grains over cell structures, given as percentages of the total number of grains counted over STH-cells of mice at each particular time interval after intravenous injection of ${ }^{3} \mathrm{H}$-amino acids $(2.8 \mathrm{mCi})$

\begin{tabular}{l|ccccccccc}
\hline & $3(\mathrm{~min})$ & 5 & 15 & 30 & 1 (hr) & 2 & 4 & 8 & 24 \\
\hline r-ER & 47.1 & 22.7 & 15.6 & 15.4 & 10.4 & 9.3 & 9.8 & 5.9 & 5.6 \\
\hline Golgi apparatus & 5.9 & 32.3 & 37.2 & 40.1 & 23.3 & 18.5 & 15.8 & 12.1 & 10.4 \\
\hline Secretory granules & 0 & 9.9 & 10.0 & 15.7 & 26.5 & 41.7 & 41.4 & 44.0 & 60.9 \\
\hline Mitochondria & 23.5 & 7.8 & 6.5 & 4.7 & 7.4 & 6.3 & 5.4 & 6.4 & 5.4 \\
\hline Matrix & 11.8 & 5.9 & 3.7 & 5.5 & 1.1 & 1.8 & 2.3 & 2.5 & 1.8 \\
\hline Nucleus & 5.9 & 17.1 & 23.9 & 15.2 & 24.6 & 19.5 & 21.0 & 26.7 & 14.1 \\
\hline Nuclear membrane & 5.9 & 4.4 & 1.7 & 1.8 & 3.3 & 1.9 & 1.4 & 1.4 & 0.8 \\
\hline Plasma membrane & 0 & 0 & 1.3 & 1.7 & 3.6 & 1.0 & 3.0 & 1.1 & 1.0 \\
\hline Total grains & 17 & 322 & 301 & 1179 & 1013 & 1301 & 735 & 637 & 1307 \\
\hline Total cells & 28 & 22 & 21 & 35 & 44 & 56 & 29 & 27 & 24 \\
\hline
\end{tabular}

Table 2. Distribution of silver grains over r-ER, Golgi apparatus and secretory granules, given as percentages of the total number counted over these cell structures of STH-cell of mice, at each particular time interval after intravenous injection of ${ }^{3} \mathrm{H}$-amino acids

\begin{tabular}{l|ccccccccc}
\hline & $3(\mathrm{~min})$ & 5 & 15 & 30 & $1(\mathrm{hr})$ & 2 & 4 & 8 & 24 \\
\hline r-ER & 88.9 & 34.9 & 24.9 & 21.6 & 17.2 & 13.4 & 14.6 & 9.7 & 7.3 \\
\hline Golgi apparatus & 11.1 & 49.8 & 59.2 & 56.4 & 38.8 & 26.7 & 23.6 & 19.5 & 13.5 \\
\hline Secretory granules & 0 & 15.3 & 15.9 & 22.0 & 44.0 & 59.9 & 61.8 & 71.1 & 79.2 \\
\hline
\end{tabular}

Table 3. Percentage of the number of labelled granules to that of total granules

\begin{tabular}{lllllllll}
\hline $3(\mathrm{~min})$ & 5 & 15 & 30 & $1(\mathrm{hr})$ & 2 & 4 & 8 & 24 \\
\hline $0(\%)$ & 0.8 & 1.6 & 3.9 & 4.6 & 5.0 & 7.2 & 8.0 & 12.3 \\
\hline
\end{tabular}

\section{Discussion}

As to the identification of the STH-cell, HEDINGER and FARQUHAR (1957) reported that the secretory granule of this type cell is round, highly electron dense, and about $350 \mathrm{~nm}$ in diameter. This opinion has been accepted by almost all the investigaters (Kurosumi, 1968). It has been believed that the secretoy granule of the STH-cell is derived from the Golgi apparatus (FARQUHAR and Wellings, 1957; ICHIKAWA, 1959).

The autoradiography is the weapon for chasing the turnover of protein synthesis 
and release of protein-secreting cells after the injection of ${ }^{3} \mathrm{H}$-amino acid (CARO and Palade, 1964; Jamieson and Palade, 1967; Pohr et al., 1967; Fujit A, 1970, NAKagami et al., 1971; CAstle et al., 1972; SLot and Geuze 1974; and so on).

The formaldehyde fixative has been believed to be more suitable than glutaraldehyde for autoradiographic study of protein synthesis, because the former has been known to cause only a low level of binding of free amino acid (Peters and Ashley, 1967; NAKAGAmi et al., 1971). For this reason, we used the formaldehyde fixative in the present study.

Absorption of amino acid into cells depends upon the quantity of free amino acid in the blood. CARO and PALADE (1964), using the guinea pig reported that acid soluble radioactivity in the blood reaches a peak in less than 1 min after the intravenous injection of ${ }^{3} \mathrm{H}$-leucine and then decreases very rapidly until it reaches a plateau at about 20 per cent of the peak value at 4 to 5 min. According to Slot and Geuze (1974), the concentration of labelled leucine in the frog blood $10 \mathrm{~min}$ after the intravenous injection of ${ }^{3} \mathrm{H}$-leucine is less than half that 2 min after the injection and at about $20 \mathrm{~min}$ there ia very slow fall in soluble radioactivity. This data might be applied for the present study. By light microscopic autoradiography, silver grains are distributed sparsely over the nucleus and cytoplasm of all kinds of anterior pituitary cells 3 min after the intravenous injection of ${ }^{3} \mathrm{H}$-amino acids and are increased in number with the lapse of time. In the animal 15 and $30 \mathrm{~min}$ after the injection, silver grains are concentrated in the region next to the nucleus. Then the grains are increased in number with time and become almost stable 4,8 and $24 \mathrm{hrs}$ after the injection. The results from the electron microscopic autoradiographs of STH-cells are similar to those in all kinds of glandular cells in light microscopic autoradiographs.

For the comparison of our results in the STH-cells of the anterior pituitary with other protein secretory organs, the data published by some investigators is shown as follows. CARO and PALADE (1964) reported that at $5 \mathrm{~min}$ after the intravenous injection of ${ }^{3} \mathrm{H}$-leucine the label is localized mostly in the $\mathrm{r}$-ER, at $20 \mathrm{~min}$ it appears in the Golgi apparatus, after $1 \mathrm{hr}$, in zymogen granules and after $4 \mathrm{hr}$ in the lumen, using the guinea pig pancreatic exocrine cell. It also has been known by SLOT and Geuze (1974) that about $10 \mathrm{~min}$ after the intravenous injection of ${ }^{3} \mathrm{H}$-leucine the label is located over the r-ER, after 20 min over some Golgi structure, especially the Golgi cisternae, after 2 and 4 hrs silver grains can be seen over mature secretory granules and labelled secretory granules are observed in the vicinity of the lumen in the frog pancreatic exocrine cell. According to PoHR et al. (1976), 15-30 min after the intraperitoneal injection of ${ }^{3} \mathrm{H}$-leucine, the labelled proteins are localized over the Golgi vesicles and Golgi cisternae, after $1 \mathrm{hr}$ located over secretory granules and after $2-4$ hrs recognized over the apical cell region in the mouse Brunner's gland cell. In the mouse thyroid epithelial cell, it has been shown by FujiT A (1970) that 15 min after the intraperitoneal injection of ${ }^{3} \mathrm{H}$-leucine the label appears in the r-ER, after $30-45 \mathrm{~min}$ in the Golgi apparatus and about $45 \mathrm{~min}$ in subapical vesicles. NAKAGAMI et al. (1971) found that 2 min after the intravenous injection of ${ }^{3} \mathrm{H}$-tyrosin the label is mainly found in the $\mathrm{r}-\mathrm{ER}$, by 5 and $10 \mathrm{~min}$ much of the label migrate from the r-ER into the Golgi apparatus, by 20 and $30 \mathrm{~min}$ some labels migrate from these into secretory granules and by $45 \mathrm{~min}$ and $1 \mathrm{hr}$ the label content decreases in the rat parathyroid cell. CASTLE et al. (1972) showed that the label is initially located (chase: $1-6$ min) over the $r-E R$ and 
subsequently moves as a wave through the Golgi complex (chase: 16-36 min), condensing vacuoles (chase: $36-56 \mathrm{~min}$ ), immature granules (chase: $56-116 \mathrm{~min}$ ) and finally mature storage granules (chase: $116-356 \mathrm{~min}$ ) using pulse labelling with ${ }^{3} \mathrm{H}$-leucine and chase incubation in the rabbit parotid acinar cell.

Our findings for the turnover of protein synthesis and release in the STH-cell show that $3 \mathrm{~min}$ after the intravenous injection of ${ }^{3} \mathrm{H}$-amino acids the number of silver grains is few in the whole STH-cell and it starts to increase at $5 \mathrm{~min}$. At $5 \mathrm{~min}$ after the injection most silver grains are found over the r-ER, Golgi apparatus and a few are over the secretory granules. This fact indicates that the exportable protein can be synthesized in the r-ER and transported to the Golgi apparatus and then to the secretory granules during only $5 \mathrm{~min}$. The label of the secretory granules increases rapidly after $2 \mathrm{hrs}$ and this condition continues until $24 \mathrm{hrs}$. These facts suggest that the secretory granules are not released so rapidly.

The present data in the STH-cell are different from those in the thyroid and parathyroid cell. The labelled granules in the thyroid and parathyroid cells are maximum in number $1 \mathrm{hr}$ and $30 \mathrm{~min}$ respectively after the injection of ${ }^{3} \mathrm{H}$-amino acid and then decrease with the lapse of time, while the labelled granules in the STH-cell continue to increase in number until $24 \mathrm{hrs}$ after the injection. The present authors wish to emphasize that newly synthesized proteins in the STH-cell are stored in secretory granules and released into the perivascular space very slowly. In other words, the turnover of the exportable protein synthesis and release in the STH-cell, especially the release, is very slow.

The data obtained from the cultured tissue of the anterior pituitary is comparable with our data obtained from the in vivo experiment. HopkIns and FARQUHAR (1973) reported that at the end of the $5 \mathrm{~min}{ }^{3} \mathrm{H}$-leucine pulse, the majority of the autoradiographic grains are diffusely distributed over the nucleus and the r-ER of STH-cells, at 15-30 min post pulse there is a striking concentration of the Golgi apparatus and at $60 \mathrm{~min}$ post pulse an increased number of silver grains can be related to secretory granules. Similarly, by Howell and Whitfield (1973), it has been clarified that the exportable proteins in the cultured STH-cell are synthesized initially on the r-ER and are transported within $10 \mathrm{~min}$ after their synthesis to transitional areas between the $\mathrm{r}$-ER and the Golgi apparatus, transfer to the Golgi lamellae is achieved within $60 \mathrm{~min}$ after synthesis, while the formation of mature storage granules occurs within 2 hrs following protein synthesis and the label of secretory granules increases with the passage of time. RACADOT et al. (1965) showed that silver grains are distributed mainly over the ergastoplasm $10 \mathrm{~min}$ after the intraperitoneal injection of ${ }^{3} \mathrm{H}$-leucine, at $30 \mathrm{~min}$ found over the Golgi apparatus and localized over secretory granules $90 \mathrm{~min}$ after the injection although distribution of silver grains over the STH-cell structures is not analysed. Our findings of in vivo experiment are not so different from their results done using in vitro tissue or in vivo experiment. 


\title{
電顕オートラジオグラフィーによるマウス下垂体成長ホルモン分泌細胞における 蛋白の合成と放出のスピードの解析
}

\author{
日 浦昌道, 小松正伸, 藤田尚男
}

下垂体前葉の成長ホルモン分泌細胞における分泌物合成, 放出のスピードを検索する目 的で, マウスを用い, 5 種のアミノ酸 ( ${ }^{3} \mathrm{H}-$ ロイシン, ${ }^{3} \mathrm{H}-$ チロジン, ${ }^{3} \mathrm{H}-$ リジン, ${ }^{3} \mathrm{H}$-ヒス チジン, ${ }^{3} \mathrm{H}$-グリシンの混合物) 它計 $2.8 \mathrm{mCi}$ づつ静脈注射し, 注射後 3 分, 5 分, 15 分, 30 分， 1 時間， 2 時間， 4 時間， 8 時間，24時間に動物を殺し，下垂体前葉のオートラジ オグラフィーを行なった.

${ }^{3} \mathrm{H}$-アミノ酸注射後 3 分では，全体の銀粒子ほ極めて少ないが，粗面小胞体に最も多い (全銀粒子の $47.1 \%)$. ゴルジ装置にもすでに少数の銀粒子が認められる (5.9\%).

細胞内の銀粒子総数は時間とともに増加していくが，各小器官の間の割合をみた場合に， 粗面小胞体におけるものは徐々に減少に向から。一方 ゴルジ装置上の銀粒子は 30 分まで 増加し (40.1\%)，それ以後は減少する.

分泌顆粒上の銀粒子は注射後 5 分から出現し, 細胞内の全粒子に対する顆粒上の粒子の 割合は時間とともに増加していく.ラベルされた顆粒の総顆粒に対する割合は 24 時間まで ゆっくりとした増加定示す (3 分：0\%,5分：0.8\%，30 分: $3.9 \%, 2$ 時間: $5.0 \%, 8$ 時間：8.0\%，24時間 : $12.3 \%)$.

以上から甲状腺や上皮小体と比べて，下垂体の成長ホルモン分泌細胞の蛋白合成および 放出の回転は きわめて緩徐であることが推測される。しかし 注射されたアミノ酸の少量 は 3 分ですでに粗面小胞体で蛋白に組み込まれ，5分でゴルジ装置や顆粒にまで達してい ることがわかる。

\section{References}

Caro, L. G. and G. E. Palade : Protein synthesis, storage, and discharge in the pancreatic exocrine cell. J. Cell Biol. 20: 473-495 (1964).

Castle, J. D., J. D. Jamieson and G. E. Palade: Radioautographic analysis of the secretory process in the parotid acinar cell of the rabbit. J. Cell Biol. 53: 290-311 (1972).

Farquhar, M. G. and S. R. Wellings : Electron microscopic evidence suggesting secretory granule formation within the Golgi apparatus. J. biophys. biochem. Cytol. 3: 319-322 (1957).

Fujita, H.: Outline of the fine structural aspects on the synthesis and release of the thyroid hormone. Gunma Symp. Endocrinol. 7: 49-63 (1970).

Hedinger, C. E. und M. G. Farquhar: Elektronenmikroskopische Untersuchungen von zwei Typen acidophiler Hypophysenvorderlappenzellen bei der Ratte. Schweiz. Z. Pathol. Bakteriol. 20: 766-768 (1957).

Hopkins, C. R. and M. G. Farquhar : Hormone secretion by cells dissociated from rat anterior pituitaries. J. Cell Biol. 59: 276-303 (1973).

Howell, S. L. and M. Whitfield : Synthesis and secretion of growth hormone in the rat anterior pituitary. J. Cell Sci. 12: 1-21 (1973). 
Ichikawa, A.: Electron microscope study on secretion of the rat adenophypophysis. (Japanese with English abstract.) Acta anat. nippon. 34: 460-482 (1959).

Jamieson, J. D. and G. E. Palade : Intracellular transport of secretory proteins in the pancreatic exocrine cell. J. Cell Biol. 34: 597-615 (1967).

Kurosumi, K. : Functional classification of cell types of the anterior pituitary gland accomplished by electron microscopy. Arch. histol. jap. 29: 329-362 (1968).

Lettré, H. und N. Paweletz : Probleme der elektronenmikroskopischen Autoradiographie. Naturwiss. 53: 268-271 (1966).

Millonig, G.: A modified procedure for lead staining of thin sections. J. Cell Biol. 11: 736-739 (1961).

Nakagami, K., H. Warshawsky and C. P. Leblond : The elaboraion of protein and carbohydrate by rat parathyroid cells as revealed by electron microscope radioautography. J. Cell Biol. 51: 596-610 (1971).

Peters, T. Jr and C. A. Ashley : An artifact in radioautography due to binding of free amino acids to tissues by fixatives. J. Cell Biol. 33: 53-60 (1967).

Pohr, H. P., J. Schmalbeck und A. Feldhege: Elektronemikroskopisch-autoradiographische Untersuchungen über die Eiweiß-Synthese in der Brunnerschen Drüse der Maus. Z. Zellforsch. 80: 183-204 (1967).

Racadot, J., L. Olivier, E. Parcile et B. Droz: Appareil de Golgi et origine des grains de sécrétion dans les cellules adénohypophysaires chez le Rat. C. r. Acad. Sci. Paris 261: 2972-2974 (1965).

Slot, J. W. and J. J. Geuze: Synthesis and intracellular transport of proteins in the exocrine pancreas of the frog (Rana esculenta). Cell Tiss. Res. 155: 135-154 (1974).

Tixier-Vidal, A. et R. Picart: Etude quantitative par radioautographie au microscope electronique de l'utilisation de la dl-leucine- ${ }^{-3} \mathrm{H}$ par les cellules de l'hypophyse du canard en culture organotypiqe. J. Cell Biol. 35: 501-519 (1967).

藤田尚男

舟734 広島市霞 $1-2-3$

広島大学医学部

第二解剖学教室
Dr. Hisao Fujita

Department of Anatomy

Hiroshima University School of Medicine

Kasumi 1-2-3

Hiroshima, 734 Japan 